\title{
Subpopulations of long-lived and short-lived $T$ cells in advanced HIV-1 infection
}

\author{
Marc K. Hellerstein, ${ }^{1,2}$ Rebecca A. Hoh, ${ }^{2}$ Mary Beth Hanley, ${ }^{3}$ Denise Cesar, ${ }^{1}$ Daniel Lee, ${ }^{1}$ \\ Richard A. Neese, ${ }^{1,2}$ and Joseph M. McCune $e^{2,3,4}$ \\ ${ }^{1}$ Department of Nutritional Sciences and Toxicology, University of California, Berkeley, Berkeley, California, USA \\ ${ }^{2}$ Department of Medicine, University of California, San Francisco, and Medical Service, San Francisco General Hospital, \\ University of California, San Francisco, San Francisco, California, USA \\ ${ }^{3}$ Gladstone Institute of Virology and Immunology, San Francisco General Hospital, University of California, San Francisco, \\ San Francisco, California, USA \\ ${ }^{4}$ Department of Microbiology and Immunology, University of California, San Francisco, San Francisco, California, USA
}

Antigenic stimulation of $\mathrm{T}$ cells gives rise to short-lived effector cells and long-lived memory cells. We used two stable isotope-labeling techniques to identify kinetically distinct subpopulations of $\mathrm{T}$ cells and to determine the effect of advanced infection with HIV-1. Long-term deuterated water $\left({ }^{2} \mathrm{H}_{2} \mathrm{O}\right)$ incorporation into DNA demonstrated biphasic accrual of total and of memory/effector $(\mathrm{m} / \mathrm{e})$-phenotype but not naive-phenotype T cells, consistent with the presence of short-lived and longer-lived subpopulations within the $\mathrm{m} / \mathrm{e}$-phenotype $\mathrm{T}$ cell pool. These results were mirrored by biphasic die-away kinetics in $\mathrm{m} / \mathrm{e}$ - but not naive-phenotype $\mathrm{T}$ cells after short-term ${ }^{2} \mathrm{H}$-glucose labeling. Persistent label retention was observed in a subset of $\mathrm{m} / \mathrm{e}$-phenotype $\mathrm{T}$ cells (presumably memory $\mathrm{T}$ cells), confirming the presence of $\mathrm{T}$ cells with very different life spans in humans. In advanced HIV-1 infection, much higher proportions of T cells were short-lived, compared to healthy controls. Effective long-term anti-retroviral therapy restored values to normal. These results provide the first quantitative evidence that long-lived and quiescent $T$ cells do indeed predominate in the $T$ cell pool in humans and determine $T$ cell pool size, as in rodents. The greatest impact of advanced HIV-1 infection is to reduce the generation of long-lived, potential progenitor $T$ cells.

J. Clin. Invest. 112:956-966 (2003). doi:10.1172/JCI200317533.

\section{Introduction}

The $T$ cell pool, like that of epithelial, hematologic, and other tissues, contains both long-lived cells and shortlived cells. Maintenance of the $\mathrm{T}$ cell pool size is believed to differ in a fundamental aspect from these other cell types, however. For the latter tissues, shortlived cells represent the great majority of the pool and serve to maintain the steady-state pool size, whereas the $\mathrm{T}$ cell pool size is believed to be regulated mainly at the level of long-lived cells (1-7). T cell homeostasis has been extensively studied in murine systems, but there

Received for publication December 3, 2002, and accepted in revised form July 3, 2003

Address correspondence to: Marc Hellerstein, University of California, Berkeley, 119 Morgan Hall, Berkeley, California 94720-3104, USA. Phone: (510) 642-0646; Fax: (510) 642-0535; E-mail: march@nature.berkeley.edu.

Conflict of interest: The technology described in this article has been patented (to the University of California and M.K.

Hellerstein) and licensed to KineMed Inc., Emeryville, California, USA. M.K. Hellerstein and R.A. Neese are consultants for and own stock in KineMed Inc.

Nonstandard abbreviations used: deuterated water $\left({ }^{2} \mathrm{H}_{2} \mathrm{O}\right)$; memory/effector (m/e); antiretroviral (ARV); San Francisco General Hospital (SFGH); General Clinical Research Center (GCRC); gas chromatography-mass spectrometry (GC/MS); long-term antiretroviral (LT ARV); excess $\mathrm{M}_{+1}$ and $\mathrm{M}_{+2}$ mass isotopomer abundances $\left(\mathrm{EM}_{1}\right.$ and $\left.\mathrm{EM}_{2}\right)$. have been few if any studies evaluating the range and pattern of T cell life spans in humans. This issue is particularly important in context of the immunopathogenesis of HIV-1 infection, which is characterized by depletion of the $\mathrm{CD} 4^{+} \mathrm{T}$ cell pool.

The life span of $\mathrm{T}$ cells can be influenced by both endogenous (physiologic) and exogenous (pathologic) factors. During the course of an antigen-driven proliferative response, some $\mathrm{T}$ cells differentiate into effector-type cells, whereas others differentiate into true memory cells. Effector $\mathrm{T}$ cells provide important functions designed to clear inciting antigens but typically exhibit a short life span delimited by activationinduced cell death $(2-5,8)$. Memory $T$ cells, by contrast, are characterized by a long life span, the ability to serve as persistent reservoirs for subsequent antigen-induced activation into effector as well as memory $\mathrm{T}$ cells, and a high proliferative potential on subsequent exposure to antigen $(2-5,8)$. Antigenindependent, or "homeostatic," proliferation $(6,7)$ can also result in the production of long-lived memory $\mathrm{T}$ cells. Naive-phenotype $\mathrm{T}$ cells also exhibit a long life span (2, 8-10). Antigen-driven T cell proliferation has been proposed to account for a high proportion of the activated or cycling cells in $T$ cell populations under normal conditions $(6,7)$. In patients with HIV-1 infection, a shortened average life span of 
$\mathrm{T}$ cells has been documented $(9,11-16)$. Whether the cause for this shortened average life span is direct cell killing by HIV-1, indirect effects of activation, or alterations in $\mathrm{T}$ cell development pathways, remains controversial $(6,7,11,12,17,18)$.

A better understanding of $\mathrm{T}$ cell homeostasis in humans might emerge if turnover rates and life spans of memory-effector-phenotype (m/e-phenotype) $\mathrm{T}$ cell populations could be characterized in detail. There are no cell surface markers that unambiguously distinguish short-lived (effector) type from longlived (memory) type $\mathrm{T}$ cells within the $\mathrm{m} / \mathrm{e} \mathrm{T}$ cell pool, however. An alternative approach would be to use a kinetic (labeling) strategy for characterizing variations in life span within this pool. Demonstration of discrete long-lived and short-lived subpopulations among $\mathrm{T}$ cells sharing the $\mathrm{m} / \mathrm{e}$ phenotype would suggest an anatomic correlate and might provide insight into the pathogenesis of $\mathrm{T}$ cell depletion induced by HIV-1 infection.

Until now kinetic methods for measuring the fate and life span of cells in humans were not available. Cell-cycle markers such as Ki67 do not provide information concerning the fate of a cell, whereas labeling with $\mathrm{BrdU}$ or ${ }^{3} \mathrm{H}$-thymidine is not readily interpretable with regard to cell survival (13) (see below), in addition to having toxicities that have generally precluded use in humans. We recently developed stable isotope-labeling methods for measuring the replication of DNA in dividing cells $(9,10,14,19,20)$, including a deuterated water-labeling $\left({ }^{2} \mathrm{H}_{2} \mathrm{O}\right.$-labeling) technique that allows very long-term studies of cell proliferation (10, 15, 20-23). Here, we describe for the first time the kinetics of long-term label incorporation into $T$ cell DNA in humans. Combined with the pattern of longterm label die-away in $T$ cell DNA after pulse labeling with ${ }^{2} \mathrm{H}$-glucose, we demonstrate that $\mathrm{T}$ cell pools in humans, and the $\mathrm{m} / \mathrm{e}$-phenotype $\mathrm{T}$ cell pool in particular, contain cells with very different life spans. We also characterize the effects of advanced HIV-1 infection and antiretroviral (ARV) therapy on T cell subpopulations with differing life spans.

\section{Methods}

Labeling protocols. The in vivo studies followed two labeling protocols: (a) Long-term ${ }^{2} \mathrm{H}_{2} \mathrm{O}$ administration. Subjects were admitted to the San Francisco General Hospital (SFGH) General Clinical Research Center (GCRC) for 24 hours for the initial administration of ${ }^{2} \mathrm{H}_{2} \mathrm{O}$ (to ensure a slow rise in initial body water enrichment and thereby avoid the possibility of vestibular symptoms) (10). The ${ }^{2} \mathrm{H}_{2} \mathrm{O}$ dosing regimen achieves plateau body water enrichments of about $1.0 \%$ to $1.5 \%$ (10) (see text below). Subjects received 7 doses $\left(70 \mathrm{ml}\right.$ each of $\left.70 \%{ }^{2} \mathrm{H}_{2} \mathrm{O}\right)$ in the SFGH GCRC over a period of 24 hours and then $70 \mathrm{ml}$ daily at home for 9 weeks. Timing of blood draws for $\mathrm{T}$ cell kinetic measurements is described below. (b) $\left[{ }^{2} \mathrm{H}\right]$ glucose incorporation/decay. Administration of $\left[6,6-{ }^{2} \mathrm{H}_{2}\right]$ glu- cose (100-200 g) was by constant i.v. infusion for 48 hours in the SFGH GCRC $(9,14,19)$. Blood draws (2 $\mathrm{ml}$ ) were taken every 6 to 12 hours for plasma glucose enrichment. Timing of blood draws for $\mathrm{T}$ cell kinetic measurements is described below.

Measurement of $T$ cell DNA labeling. The stable isotope/FACS/mass spectrometric method for measuring $\mathrm{T}$ cell proliferation has been described in detail previously $(9,10,14)$. A brief description follows.

Flow cytometry. $\mathrm{CD}^{+}$or $\mathrm{CD}^{+} \mathrm{T}$ cells with the $\mathrm{CD}^{2} 5 \mathrm{RA}^{+} \mathrm{CD} 62 \mathrm{~L}^{+}$phenotype were retrieved as naivephenotype $T$ cells on a dual laser (argon $310 \mathrm{~nm}$, argon $488 \mathrm{~nm}$ ) FACS Vantage (Becton Dickinson Immunocytometry Systems, San Jose, California, USA); all other subpopulations of $\mathrm{T}$ cells were collected together as m/e-phenotype T cells (9).

Measurement of isotopic enrichment in T cell DNA. Deoxyadenosine was prepared from T cell DNA by enzymatic hydrolysis, followed by separation on an LC18 SPE column (Supelco, Bellefonte, Pennsylvania, USA) (20). Samples were reduced with $\mathrm{NaBH}_{4}$ (SigmaAldrich, St. Louis, Missouri, USA) in water (40 $\mathrm{mg} / \mathrm{ml}$ ), followed by acetylation of the deoxyribose moiety with acetic anhydride using 1-methylimidazole as a catalyst (20).

Gas chromatography-mass spectrometry (GC/MS) analysis using an HP model 5973 MS with a 6890 GC and autosampler (Hewlett-Packard, Palo Alto, California, USA) was by methane CI, with a 30-m DB-225 column under selected ion monitoring of $\mathrm{m} / \mathrm{z} 245$ 247. For ${ }^{2} \mathrm{H}_{2} \mathrm{O}$ labeling, the excess $\mathrm{M}_{+1}\left(\mathrm{EM}_{1}\right)$ mass isotopomer abundance was calculated (10); for $\left[6,6-{ }^{2} \mathrm{H}_{2}\right]$ glucose labeling, the excess $\mathrm{M}_{+2}\left(\mathrm{EM}_{2}\right)$ mass isotopomer abundance was calculated $(9,19)$. $\mathrm{EM}_{1}$ and $\mathrm{EM}_{2}$ values represent isotope enrichment above natural abundance, from ${ }^{2} \mathrm{H}_{2} \mathrm{O}$ and $\left[{ }^{2} \mathrm{H}_{2}\right]$ glucose, respectively, and are analogous to specific activity values with radio isotopes $(14,24)$.

Measurement of body ${ }^{2} \mathrm{H}_{2} \mathrm{O}$ and blood glucose enrichments. Body water enrichments were determined by a GC/MS technique $(10,20)$. Blood glucose enrichments were measured from samples drawn every 6 to 12 hours during the i.v. infusions of ${ }^{2} \mathrm{H}$-glucose by a GC/MS technique $(9,14,19)$.

Human subjects. Subjects were recruited by advertisement. Written informed consent was obtained and protocols were approved by the University of California at San Francisco and the University of California at Berkeley Committees on Human Research. In HIV-1seronegative controls, $\mathrm{CD} 4^{+} \mathrm{T}$ cell counts were $940 \pm 120$ and CD8 counts were $660 \pm 80$ cells/ $\mu$ l. In subjects with untreated, advanced HIV-1 disease (the advanced HIV-1/AIDS group), the $\mathrm{CD}^{+} \mathrm{T}$ cell count was $275 \pm 110$ cells $/ \mathrm{mm}^{3}$, the $\mathrm{CD}^{+} \mathrm{T}$ cell count was $1145 \pm 580$ cells $/ \mathrm{mm}^{3}$, and the log plasma HIV-1 RNA was $4.5 \pm 1.2$ copies $/ \mathrm{ml}$ (mean $\pm \mathrm{SD}$ for all parameters). Subjects had stable $\mathrm{CD} 4^{+} \mathrm{T}$ cell counts over the preceding 30 days and no active opportunistic infections during the preceding 60 days. In subjects on effective long- 
term ARV (LT ARV) therapy (including at least one protease inhibitor and two nucleoside reverse-transcriptase inhibitors; the LT ARV therapy group), the $\mathrm{CD}^{+} \mathrm{T}$ cell counts were $427 \pm 96$ cells $/ \mathrm{mm}^{3}$ and the plasma HIV-1 RNA level was below detection limit ( $<50$ copies $/ \mathrm{ml}$ ) for at least 12 months.

Calculations of T cell kinetic parameters. ${ }^{2} \mathrm{H}_{2} \mathrm{O}$ kinetic calculations were based on the precursor-product relationship, according to the rise to plateau principle, and were carried out as described in detail previously $(9,10,14,19)$.

The precursor pool enrichment was calculated in the ${ }^{2} \mathrm{H}_{2} \mathrm{O}$ cell proliferation studies from measurements of a fully turned-over cell type (monocytes or granulocytes in humans) (10). Blood monocyte and granulocyte deoxyadenosine enrichments were measured at the time of each $\mathrm{T}$ cell kinetic measurement. Monocytes were isolated as $\mathrm{CD} 14^{+}$expressing cells, using immunomagnetic beads (Miltenyi Inc., Auburn, California, USA). Granulocytes were isolated by use of ficollhypaque gradient (13). Incorporation and decay kinetics of ${ }^{2} \mathrm{H}$-glucose in $\mathrm{T}$ cells were calculated as described previously $(9,14,19,24)$.

Statistical analyses. Groups were compared by one-way ANOVA with Dunn/Bonferoni follow-up at a procedurewise error rate of $5 \%$.

Techniques for identifying T cell subpopulations with different life spans. The basic principle used here was to document the presence of $\mathrm{T}$ cells with widely different life spans on the basis of their labeling behavior rather than on surface markers or other molecular features. If discrete subpopulations of cells with different life spans (kinetically distinct subpopulations) are present within a biologic pool of interest, label incorporation and label decay will reveal biphasic (or multiphasic) kinetics $(23,24)$. During continuous label administration, a subpopulation that is turning over (proliferating and dying) rapidly will dominate the initial label incorporation phase but will quickly reach an isotopic plateau wherein death of labeled, short-lived cells balances out continued label incorporation into newly divided cells. If there is subsequent accrual of label in the mixed population, this signifies proliferation of a second subpopulation that is turning over more slowly. Thus, the rate of accrual of labeled cells should be greater at early time points than at later time points. Deconvolution of the early and late label incorporation phases then allows estimation of input from each of the kinetically distinct subfractions $(23,24)$. For such an evaluation to proceed, however, an experimental technique must be available that allows label administration for a period that is much longer than the turnover time of the short-lived pool $(10,13)$.

Similarly, after pulse labeling, the die-away curve of a population with discrete short-lived and long-lived components will not approach zero in a monoexponential fashion. The longer-lived subpopulation will result in labeled cells that remain after the initial rapid label die-away phase; the short-lived fraction of cells will be discernable by the initial drop-off from peak labeling. To use the postlabeling behavior of a pool for identifying discrete short-lived and long-lived subpopulations, however, an experimental technique must be available that allows a true pulse-chase to be performed - i.e., one wherein label washout from the precursor pool is rapid and label die-away within the product pool is interpretable in a simple manner (13, 24, 25). Die-away curves after BrdU-labeling of DNA, for example, do not reflect cell death in a predictable manner (because of continued BrdU-positivity of daughter cells for several generations of cell division, followed by a threshold drop-off to BrdU-negativity; see below). In contrast, die-away after endogenous labeling of the deoxyribose moiety of purine deoxyribonucleotides in DNA with $\left[{ }^{2} \mathrm{H}_{2}\right]$ glucose does directly reflect cell death (13).

Accordingly, we used two complementary in vivo, stable isotope-labeling techniques (Figure 1): longterm ${ }^{2} \mathrm{H}_{2} \mathrm{O}$ administration and ${ }^{2} \mathrm{H}$-glucose incorporation/die-away curves.

The long-term ${ }^{2} \mathrm{H}_{2} \mathrm{O}$ labeling technique has recently been developed for measuring the proliferation of slowturnover cells $(14,21,22) .{ }^{2} \mathrm{H}_{2} \mathrm{O}$ enters into each of the $\mathrm{C}-\mathrm{H}$ bonds of deoxyribose in replicating DNA through the de novo nucleotide synthesis pathway (19). In all respects, other than the duration of label retention in the body, ${ }^{2} \mathrm{H}_{2} \mathrm{O}$ labeling is conceptually identical to ${ }^{2} \mathrm{H}$-glucose labeling of DNA $(9,19,20)$. Because ${ }^{2} \mathrm{H}_{2} \mathrm{O}$ can be given orally and because it persists in equilibrium with the slowly turning over total body water pool, labeling with ${ }^{2} \mathrm{H}_{2} \mathrm{O}$ has the substantial advantage of allowing very long-term labeling protocols.

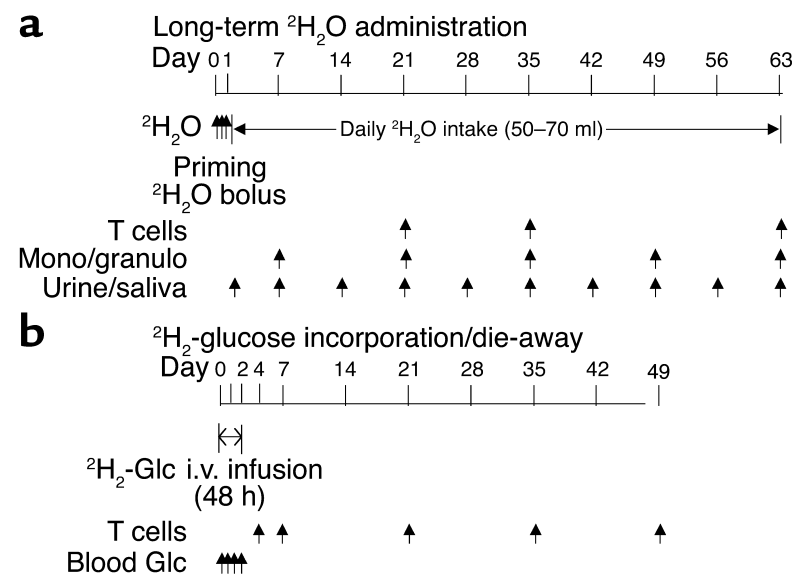

\section{Figure 1}

In vivo stable isotope labeling protocols. (a) Long-term ${ }^{2} \mathrm{H}_{2} \mathrm{O}$ administration. ${ }^{2} \mathrm{H}_{2} \mathrm{O}$ was given daily for 9 weeks after a priming regimen. T cells and monocytes/granulocytes were sampled at times shown. Urine and saliva were sampled as shown, to measure body ${ }^{2} \mathrm{H}_{2} \mathrm{O}$ enrichment. (b) ${ }^{2} \mathrm{H}_{2}$-glucose incorporation/die-away curves. ${ }^{2} \mathrm{H}_{2}$-glucose was given over 48 hours with follow-up blood draws for $T$ cells as shown. Blood glucose enrichments were measured during the i.v. ${ }^{2} \mathrm{H}_{2}$-glucose infusion. Mono/granulo, monocytes/granulocytes; Glc, glucose. Arrows indicate times of stable isotope label administration or sample collection. 


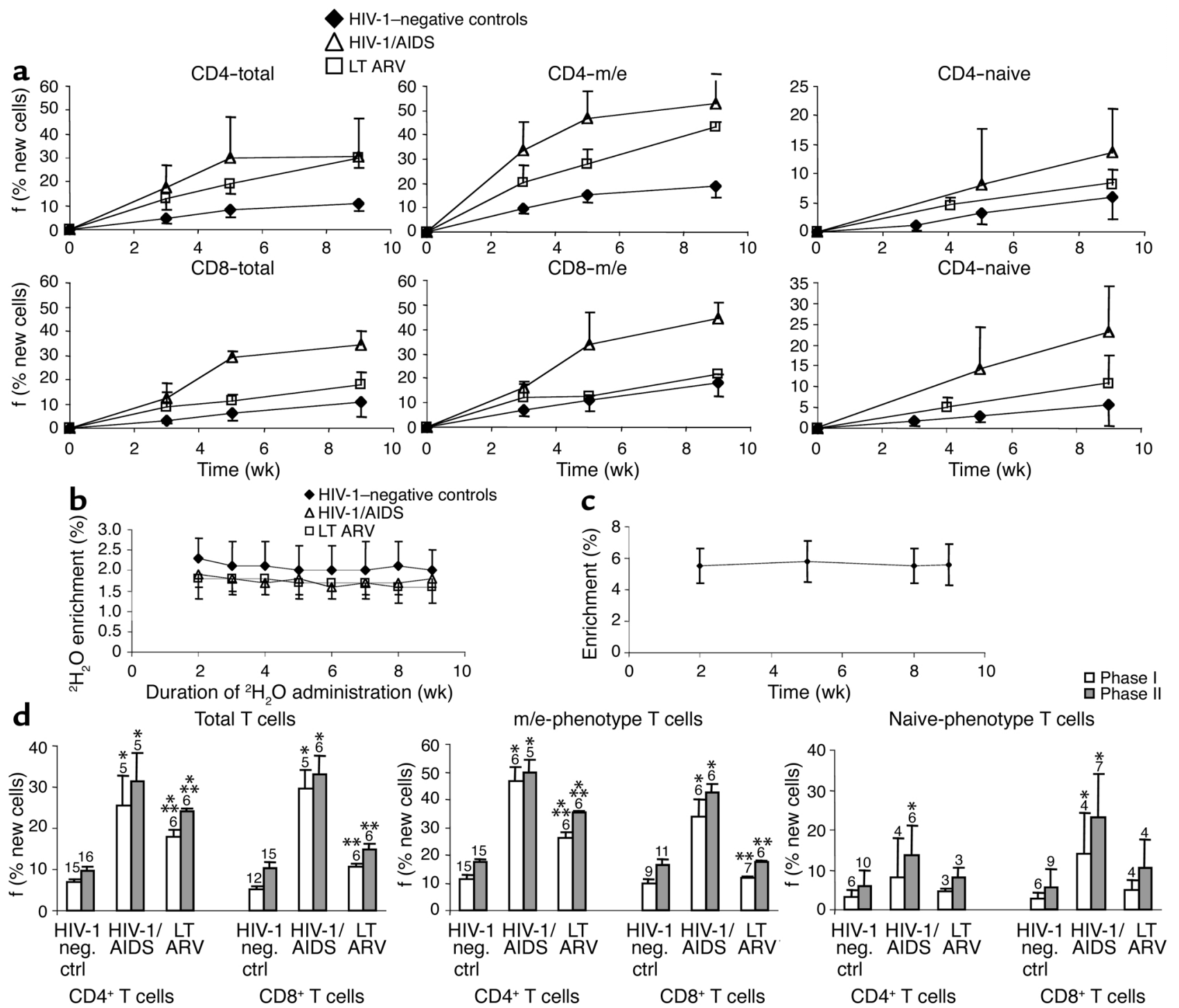

Figure 2

Time course of long-term oral ${ }^{2} \mathrm{H}_{2} \mathrm{O}$ label incorporation into $\mathrm{CD} 4^{+}$and $\mathrm{CD} 8{ }^{+} \mathrm{T}$ cell DNA in different groups. (a) Time course of fractional synthesis of T cell DNA in different clinical groups. $\mathrm{f}$, fractional synthesis or percent newly divided cells present, as described in Results. (b) ${ }^{2} \mathrm{H}_{2} \mathrm{O}$ enrichment in body water. ${ }^{2} \mathrm{H}_{2} \mathrm{O}$ was given as an initial loading dose on day 0 then given daily for 9 weeks by mouth. Urine and saliva were collected weekly and ${ }^{2} \mathrm{H}_{2} \mathrm{O}$ enrichment was measured by GC/MS (10, 22). (c) ${ }^{2} \mathrm{H}$-enrichment in blood monocytes/granulocytes (average for group as a whole). (d) Summary of phase I and phase II T cell proliferation during long-term ${ }^{2} \mathrm{H}_{2} \mathrm{O}$ incorporation in the three groups: healthy controls, untreated HIV-1/AIDS, and LTARV therapy. ${ }^{*} P<0.05$ vs. normal controls; ${ }^{*} P<0.05$ vs. HIV-1/AIDS. Number of subjects shown above bars. Data shown are mean \pm SD.

The ${ }^{2} \mathrm{H}$-glucose labeling and die-away techniques for $\mathrm{T}$ cell kinetics have been described previously $(9,14,15)$.

\section{Results}

Long-term ${ }^{2} \mathrm{H}_{2} \mathrm{O}$ administration. The incorporation curves for sort-purified total and $\mathrm{m} / \mathrm{e}$-phenotype $\mathrm{T}$ cells were measured in subjects given oral ${ }^{2} \mathrm{H}_{2} \mathrm{O}$ to maintain constant body ${ }^{2} \mathrm{H}_{2} \mathrm{O}$ enrichments for 9 weeks. Two discrete phases were apparent in all groups of subjects (Figure 2a): an initial period (phase I, up to week 5) characterized by relatively rapid accrual of newly divided cells, and a later period (phase II, through the completion of label administration at week 9) characterized by slower accrual of newly divided cells. Body ${ }^{2} \mathrm{H}_{2} \mathrm{O}$ enrichments were stable after the initial several days (Figure $2 b$ ) and therefore cannot explain nonlinearity (two phases) of labeling in DNA. Enrichment of DNA from monocytes and granulocytes was similarly constant (Figure 2c). The biphasic kinetic pattern in $T$ cells was most apparent in patients with advanced HIV-1/AIDS (Figure 2a) (see below). Comparison of average values in the clinical groups, summarized for phase I and II proliferation, is shown in Figure 2d. The phase I labeling in total $\mathrm{CD}^{+}$and $\mathrm{CD}^{+} \mathrm{T}$ cells during long-term ${ }^{2} \mathrm{H}_{2} \mathrm{O}$ incorporation was considerably higher in untreated HIV-1/AIDS sub- 

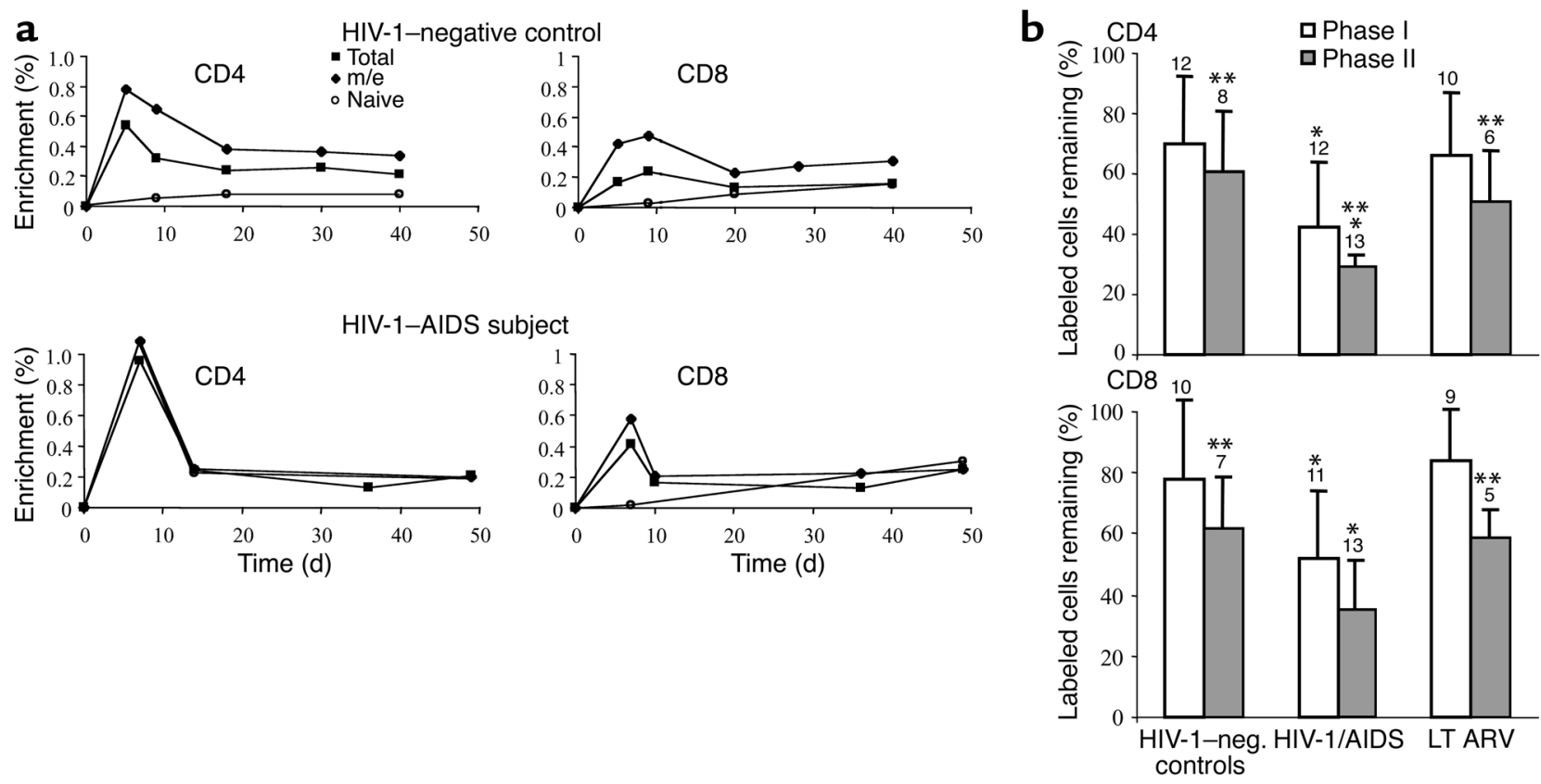

\section{Figure 3}

Time course of label die-away after intravenous ${ }^{2} \mathrm{H}$-glucose incorporation into $\mathrm{CD}^{+}$and $\mathrm{CD} 8^{+} \mathrm{T}$ cell DNA in different groups. (a) Representative ${ }^{2} \mathrm{H}$-glucose incorporation/decay curves in $\mathrm{CD} 4^{+} \mathrm{T}$ cell DNA. A healthy HIV-1 seronegative control subject (top panels) and an HIV-1/AIDS subject (bottom panels) are shown. Persistently labeled $\mathrm{m} / \mathrm{e}$-phenotype cells presumably represent true memory $\mathrm{T}$ cells; cells that die-away in phase I presumably represent short-lived, effector-type T cells. (b) Mean values of fractional die-away of labeled $\mathrm{CD}^{+}$and $\mathrm{CD} 8^{+} \mathrm{T}$ cells after pulse i.v. ${ }^{2} \mathrm{H}$-glucose administration in HIV-1-seronegative controls $(n=12)$, untreated HIV-1/AIDS $(n=13)$, and long-term effective ARV therapy (LT ARV) $(n=10)$. The fractions of labeled cells remaining after phase I die-away (through week 3 after label administration) and phase II die-away (through weeks $5-7$ ), both compared with peak labeling, are shown. ${ }^{*} P<0.05$ vs. controls. ${ }^{*} P<0.05$ vs. phase I die-away (by paired $t$ test).

jects $\left(25.4 \%\right.$ and $29.5 \%$ new cells, for $\mathrm{CD}^{+}$and $\mathrm{CD}^{+} \mathrm{T}$ cells, respectively) than in healthy seronegative controls $(6.8 \%$ and $5.3 \%$, respectively) (Figure $2 \mathrm{~d}$, left panel). The final phase II value attained was also higher in untreated HIV-1/AIDS patients (31.3\% and $33.1 \%$, respectively) than in seronegative controls ( $9.8 \%$ and $10.2 \%$, respectively). Similar findings with even greater absolute differences were apparent for $\mathrm{m} / \mathrm{e}$-phenotype $\mathrm{T}$ cells (Figure $2 \mathrm{~b}$, middle). In seronegative controls, $11.4 \%$ (phase I) and $17.2 \%$ (phase II) of m/e-phenotype $\mathrm{CD}^{+} \mathrm{T}$ cells were newly formed, compared with threeto fourfold higher values $(46.5 \%$ and $50.0 \%$, respectively) in HIV-1/AIDS patients. The values for $\mathrm{m} / \mathrm{e}-$ phenotype $\mathrm{CD}^{+} \mathrm{T}$ cells were $9.8 \%$ and $16.6 \%$ (phases I and II, respectively) in healthy controls and $33.8 \%$ and $42.8 \%$ in advanced HIV-1/AIDS. Thus, the vast majority of $\mathrm{CD}^{+}$and $\mathrm{CD}^{+} \mathrm{T}$ cells, including those of $\mathrm{m} / \mathrm{e}-$ phenotype, do not divide in HIV-1-seronegative subjects over the course of 9 weeks, whereas widespread proliferation occurs within the $\mathrm{m} / \mathrm{e}$-phenotype $\mathrm{T}$ cell pool in subjects with untreated HIV-1/AIDS. In patients with effective LT ARV therapy, the final values obtained after phase II were intermediate between the other two groups $(24.3 \%$ of total and $35.4 \%$ of $\mathrm{m} / \mathrm{e}-$ phenotype $\mathrm{CD}^{+} \mathrm{T}$ cells; $14.7 \%$ of total and $17.6 \%$ of $\mathrm{m} / \mathrm{e}$-phenotype $\mathrm{CD}^{+} \mathrm{T}$ cells, Figure $2 \mathrm{~d}$ ). Effective LT ARV therapy resulted in significantly lower values in both phase I and phase II for $\mathrm{CD} 4^{+}$and $\mathrm{CD} 8^{+}$total and $\mathrm{m} / \mathrm{e}$-phenotype $\mathrm{T}$ cells compared with the advanced HIV-1/AIDS group, although not to normal values.

The replacement rates of naive-phenotype $T$ cells were lower than those observed for total or $\mathrm{m} / \mathrm{e}$-phenotype $\mathrm{T}$ cells (Figure $2 \mathrm{a}$ ), consistent with previous results with ${ }^{2} \mathrm{H}$-glucose labeling (9). Label incorporation curves for naive-phenotype T cells were much closer to linear (Figure 2a) with the accrual of newly divided cells during phase I similar to the accrual rate during phase II. The summarized kinetic data for naive-phenotype $T$ cells (Figure $2 \mathrm{~d}$, right panel) also demonstrated a trend toward higher replacement rates for $\mathrm{CD}^{+}$and $\mathrm{CD}^{+}$cells in advanced HIV-1/AIDS patients compared with controls $\left(P<0.05\right.$ for $\mathrm{CD}^{+}$cells, HIV-1/ AIDS vs. HIV-1-negative controls, at weeks 5 and 9), with near normalization in ARV-treated patients.

Proliferation rates of $\mathrm{m} / \mathrm{e}$-phenotype $\mathrm{T}$ cells were consistently higher than for total $\mathrm{T}$ cells, as expected from the absence of the slower turnover naive-phenotype cells in the $\mathrm{m} / \mathrm{e}$-phenotype population (Figure $2 \mathrm{a}$ ). This difference between total and $\mathrm{m} / \mathrm{e}$-phenotype $\mathrm{T}$ cells was less apparent, though still present, in the $\mathrm{CD}^{+}$cells, perhaps reflecting somewhat higher proliferation of naive-phenotype $\mathrm{CD}^{+} \mathrm{T}$ cells (Figure $2 \mathrm{a}$ ).

${ }^{2} \mathrm{H}$-glucose incorporation/die-away curves. Although accrual of newly divided total and $\mathrm{m} / \mathrm{e}$-phenotype $\mathrm{T}$ 
cells was clearly nonlinear in the above-described studies using long-term ${ }^{2} \mathrm{H}_{2} \mathrm{O}$ administration in advanced HIV-1/AIDS patients, these findings were more subtle in healthy controls (Figure 2a). It is also difficult to distinguish with certainty between slow accrual and no accrual of newly divided $T$ cells during phase II (i.e., "pseudo-plateau" vs. plateau, Figure 2a), because the second phase represented a relatively small change on top of an already large number. Distinguishing between pseudo-plateau and true plateau is, however, important in the context of $\mathrm{T}$ cell subpopulations. The former interpretation is consistent with kinetically distinct subpopulations (i.e., shortlived and long-lived cells, as discussed previously), whereas the latter result might suggest the presence of only a short-lived, rapid turnover pool and a quiescent, nonturning over pool $(24,25)$. The best way to distinguish between these two models is to measure directly the kinetic fate of recently divided $\mathrm{T}$ cells.

Accordingly, a 48-hour i.v. infusion of ${ }^{2} \mathrm{H}$-glucose was performed to directly measure the die-away curves of labeled T cells. Peak label incorporation (observed in blood samples taken at days 3-5 and 6-8 after initiation of i.v. label infusion) was compared with labeled cells remaining after about 3 weeks (days 18-25) and after 5 to 7 weeks (days 35-49) (Figure 3a and Table 1). Data from 12 uninfected and 13 HIV-1-infected subjects revealed that the fractional die-away (drop-off in fraction of labeled cells present) during the first 3 weeks (phase I) was considerably greater than the subsequent die-away from weeks 3 to 7 (phase II) for total and $\mathrm{m} / \mathrm{e}$ T cells (Figure $3 \mathrm{~b}$ ). During weeks 3 to 7 , a relatively constant fraction of labeled $\mathrm{T}$ cells persisted (Figure 3a). This biphasic die-away was not observed for naive-phenotype $\mathrm{T}$ cells (Figure $3 \mathrm{a}$ ).

In HIV-1-seronegative controls, $70 \%$ of labeled total $\mathrm{CD} 4^{+} \mathrm{T}$ cells remained after the first-phase die-away and $61 \%$ of initially labeled cells remained after the second phase (Figure $3 b$, Table 1). In contrast, a much lower fraction of labeled total $\mathrm{CD} 4^{+} \mathrm{T}$ cells remained after both die-away periods in untreated advanced HIV- 1 infection (only $42 \%$ and $29 \%$ of initially labeled cells remained after the phase I and phase II periods, respectively). Effective LT ARV therapy restored $\mathrm{CD} 4^{+}$ $\mathrm{T}$ cell survival rates to normal $(66 \%$ and $51 \%$ remaining, Figure $3 \mathrm{~b})$. Die-away fractions for $\mathrm{CD}^{+} \mathrm{T}$ cells gave similar results (78\% and $62 \%$ survival for HIV-1seronegative controls after phases I and II, respectively; $52 \%$ and $35 \%$ for HIV-1/AIDS patients; and $84 \%$ and $59 \%$ for LT ARV-treated patients). Results from individual subjects in each group are shown in Table 1. Considerable interindividual variability was present within each clinical group.

In a subset of subjects, $\mathrm{m} / \mathrm{e}$ - and naive-phenotype $\mathrm{T}$ cell die-away curves were measured. Because $80 \%$ to $90 \%$ of total $\mathrm{T}$ cell proliferation generally occurs in the $\mathrm{m} / \mathrm{e}$-phenotype population after pulse ${ }^{2} \mathrm{H}$-glucose labeling (9) and naive-phenotype T cells did not exhibit significant die-away, the die-away curves for $\mathrm{m} / \mathrm{e}$ -

phenotype $\mathrm{T}$ cells typically paralleled those for total $\mathrm{T}$ cells (Figure 3a). Percent survival of $\mathrm{m} / \mathrm{e}$-phenotype $\mathrm{CD}^{+} \mathrm{T}$ cells was $55 \%$ and $41 \%$ (after phases I and II, respectively, $n=6$ ) in HIV-1-seronegative controls, $40 \%$ and $22 \%$ in HIV-1/AIDS patients $(n=5)$, and $73 \%$ and $49 \%$ in LT ARV therapy patients $(n=5)$. Similar trends, though somewhat higher survival rates, were observed for $\mathrm{m} / \mathrm{e}$-phenotype $\mathrm{CD}^{+} \mathrm{T}$ cells $(72 \%$ and $65 \%$, phases I and II, in HIV-1-seronegative controls $[n=5] ; 60 \%$ and $41 \%$ for HIV-1/AIDS [ $n=6] ; 80 \%$ and $55 \%$ for LT

\section{Table 1}

${ }^{2} \mathrm{H}$-glucose die-away results in individual subjects from different groups

$\begin{array}{ccccc}\text { Subject } & \text { Phase I (\% remaining) } & \text { Phase II (\% remaining) } \\ & \text { CD4 } & \text { CD8 } & \text { CD4 } & \text { CD8 }\end{array}$

\section{Group I: Healthy controls}

1
2
3
4
5
6
7
8
9
10
11
12

12

Mean \pm SD

(n)

Group II: HIV-1/AIDS

1

2

3

4

5

6

7

8

9

10

11

12

13

Mean \pm SD

(n)

Group III: LT ARV

1

2

3

4

5

6

7

8

9

10

Mean \pm SD

(n)

\begin{tabular}{cc}
41 & 105 \\
66 & 42 \\
73 & 101 \\
34 & 85 \\
75 & 9 \\
86 & 79 \\
73 & 38 \\
103 & 102 \\
53 & 86 \\
71 & \\
104 & 48 \\
57 & \\
\hline 022 & $78 \pm 2$
\end{tabular}

(12)

105
42
101
85
90
79
38
102
86
-
48
-
$78 \pm 26$

(10)

\section{1}

75

60

33

26

$-$

$$
38
$$

$$
29
$$$$
51
$$$$
33
$$$$
64
$$$$
38
$$$$
91
$$

$52 \pm 22$

(11)
(12)

40
102
52
74
74
50
81
57
42
89
$66 \pm 21$

(10)

\section{-}

89
61

$$
68
$$$$
69
$$$$
100
$$$$
103
$$$$
105
$$$$
68
$$$$
92
$$$$
84 \pm 17
$$

(9)

$\begin{array}{ll}32 & - \\ 82 & 67 \\ - & - \\ - & - \\ 69 & 70 \\ - & 63 \\ 54 & 27 \\ 67 & 77 \\ 40 & 57 \\ 52 & - \\ 91 & 76 \\ - & -\end{array}$

$61 \pm 20$

(8)

(7)

$\begin{array}{cc}65 & 67 \\ 39 & 37 \\ 36 & 51 \\ 15 & 27 \\ 30 & 42 \\ 29 & 32 \\ 10 & 43 \\ 14 & 20 \\ 33 & 41 \\ 19 & 12 \\ 20 & 28 \\ 31 & 8 \\ 35 & 49 \\ 29 \pm 14 & 35 \pm 16\end{array}$

(13)

53

69

52

51

69

$-$

$-$

$-$

$-$

$59 \pm 9$

$51 \pm 17$

(5) 
a Production rates (cells/ $/ \mathrm{l} / \mathrm{d}$ )

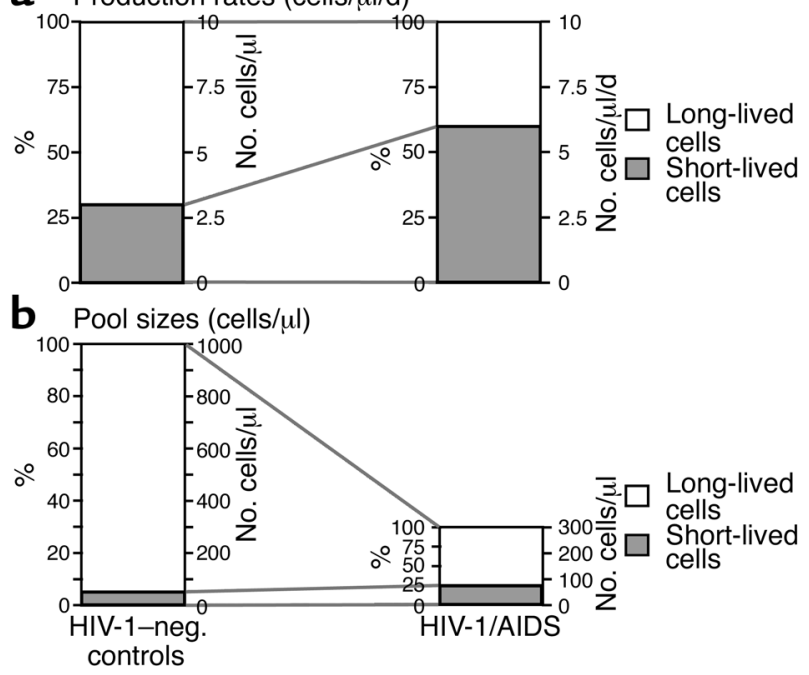

\section{Figure 4}

Calculations regarding production rates and pool sizes of kinetically distinct subpopulations of $\mathrm{CD}^{+} \mathrm{T}$ cells, with comparison between healthy control subjects and advanced HIV-1/AIDS patients. Basis of quantitative estimations is described in Results. An average CD4 ${ }^{+}$ T cell count of 1000 cells $/ \mu$ l (healthy controls) and 300 cells $/ \mu$ l (HIV-1/AIDS) was used in the calculations. (a) Daily production rates of kinetically distinct subpopulations (cells/ $\mu \mathrm{l} /$ day). (b) Pool sizes of kinetically distinct subpopulations (cells/ $\mu \mathrm{l})$.

ARV patients $[n=4])$. Naive-phenotype T cells did not exhibit a die-off during the 3 to 6 weeks after ${ }^{2} \mathrm{H}$-glucose labeling, but instead exhibited an increase in the labeled fraction of cells. Label from $\left[6,6{ }^{2} \mathrm{H}_{2}\right]$ glucose in DNA was barely detectable $(<0.05 \%)$ at days 5 to 8 but increased to $0.11 \%$ (week 3 ) and $0.32 \%$ (week 6) for naive-phenotype $\mathrm{CD}^{+}$cells and to $0.18 \%$ (week 3 ) and $0.22 \%$ (week 6) for naive-phenotype $\mathrm{CD}^{+}$cells $(n=3$ healthy controls). We interpret this delayed increase in naive-phenotype $\mathrm{T}$ cell labeling as representing the time lag for maturation and/or release of newly divided naive-phenotype $T$ cells into the circulation.

These results are similar to observations after antigen stimulation of $\mathrm{T}$ cells in rodents $(1,2,8)$, wherein an initial period of expansion is followed first by a phase in which many effector cells die and then by one exhibiting long-term persistence of true memory cells. By analogy with these studies $(2-5,8)$, the shorter-lived cells observed here may represent effector-type $\mathrm{T}$ cell subpopulations, whereas the longer-lived cells may include subpopulations of true memory $\mathrm{T}$ cells. Given the demonstration of these kinetically distinct populations, it may now be possible to determine which phenotypic markers are best used to distinguish these subpopulations from one another.

Calculation of pool sizes and turnover rates of kinetically distinct subpopulations of $T$ cells. By combining the above labeled die-away and long-term incorporation results, it is possible to calculate the pool sizes of kinetically distinct subpopulations of $\mathrm{T}$ cells in these subjects. Calculations were performed as follows. The fraction of short-lived cells in the total $\mathrm{CD} 4^{+} \mathrm{T}$ cell pool was calculated from the proportion of labeled cells lost during phase I die-away (Table 1, Figure 3). Absolute T cell production rates were calculated from the fractional replacement rate per day (based on ${ }^{2} \mathrm{H}$-glucose incorporation) multiplied times the $\mathrm{CD} 4$ count, as described previously $(9,14)$. Average life span of short-lived cells was estimated on the basis of die-away curves after ${ }^{2} \mathrm{H}$-glucose labeling (Figure 3a). Pool size was then calculated from daily production rate (cells per day) multiplied times the average life span (days). Cells that are not short-lived were taken to be long-lived. These calculated values for short-lived cells were then compared with measured newly divided total $\mathrm{CD} 4^{+} \mathrm{T}$ cells during phase I of ${ }^{2} \mathrm{H}_{2} \mathrm{O}$ labeling (Figure 2d). By combining these measurements, the following results were obtained. Short-lived cells (likely, effector $\mathrm{CD}^{+} \mathrm{T}$ cells) represented about $30 \%$ of newly divided total $\mathrm{CD}^{+}$ $\mathrm{T}$ cells in HIV-1-seronegative subjects (Figure 4a). Because the total production rate of circulating $\mathrm{CD}^{+}$ $\mathrm{T}$ cells was about 10 cells $/ \mu \mathrm{l} / \mathrm{d}$, consistent with previous results $(9,14)$, roughly three $\mathrm{CD} 4^{+}$short-lived $\mathrm{T}$ cells are produced per microliter of blood per day (Figure 4a). These cells, as identified here, appear to live for 14 to 21 days (Figure 3a), so the pool size of such shortlived $\mathrm{CD} 4^{+} \mathrm{T}$ cells can be estimated to comprise roughly 40 to 60 cells $/ \mu$ l, or $4 \%$ to $6 \%$ of the total $\mathrm{CD}^{+} \mathrm{T}$ cell pool of 1000 cells $/ \mu \mathrm{l}$ (Figure $4 \mathrm{~b}$ ). This estimate is consistent with the results from ${ }^{2} \mathrm{H}_{2} \mathrm{O}$ incorporation (6.8\% total $\mathrm{CD}^{+} \mathrm{T}$ cells labeled after phase $\mathrm{I}^{2}{ }^{2} \mathrm{H}_{2} \mathrm{O}$, Figure 2d). In subjects with advanced HIV-1/AIDS, a much larger fraction (about $55 \%-60 \%$ ) of newly divided cells was short lived (Figure 4a). The total $\mathrm{CD}^{+} \mathrm{T}$ cell production rate in these subjects is also about 9 to 10 cells $/ \mu \mathrm{l} / \mathrm{d}(9,14)$, yielding a production rate of about 5.5 short-lived $\mathrm{CD}^{+} \mathrm{T}$ cells $/ \mu \mathrm{l} / \mathrm{d}$ (Figure $4 \mathrm{a}$ ) and (assuming a life span of 10-14 days, Figure 1) (15) a total pool size of roughly 55 to 75 cells/ $\mu \mathrm{l}$, or $20 \%$ to $25 \%$ of the total $\mathrm{CD}^{+}$pool of 300 cells/ $\mu$ (Figure $4 \mathrm{~b}$ ). Again, these calculations are consistent with the ${ }^{2} \mathrm{H}_{2} \mathrm{O}-$ labeling results $\left(25.4 \%\right.$ total $\mathrm{CD} 4{ }^{+} \mathrm{T}$ cells labeled after phase $\mathrm{I}^{2} \mathrm{H}_{2} \mathrm{O}$ labeling, Figure 2d). Thus, the kinetics of short-lived cells dominates after the pulse labeling of subjects with advanced HIV-1/AIDS (9, 14-16), but the total pool size of this short-lived subpopulation is only modestly changed (Figure 4b).

The production rates and pool sizes of long-lived $\mathrm{CD}^{+} \mathrm{T}$ cells are also of interest. This kinetically distinct subpopulation includes cells that are either nondividing (over the course of 9 weeks) or only slowly dividing, and comprises cells with an $\mathrm{m} / \mathrm{e}$ or a naive phenotype. In normal controls, about seven long-lived $\mathrm{CD}^{+} \mathrm{T}$ cells are produced per microliter per day (Figure 4a). The pool size of such long-lived cells can be estimated to be approximately 940 to 960 cells/ $\mu$ l, or about $95 \%$ of the total CD $4^{+} \mathrm{T}$ cell pool of 1000 cells/ $\mu \mathrm{l}$ (Figure $4 \mathrm{~b}$ ). By contrast, only 3.5 to 4.0 long-lived cells are produced per microliter per day in subjects with HIV-1/AIDS (Figure 4a). This is associated with a pool size of 225 to 245 
cells $/ \mu \mathrm{l}$, or $75 \%$ to $80 \%$ of a total $\mathrm{CD} 4^{+} \mathrm{T}$ cell pool of 300 cells/ $\mu$ l. Thus, although the total pool size of short-lived cells is only modestly affected in later stages of HIV-1 disease, the capacity to produce long-lived (i.e., naive and presumably true memory) $\mathrm{CD} 4^{+} \mathrm{T}$ cells and to keep such cells quiescent over time is deficient, with a reduction in the circulating long-lived pool size from 940 to 960 cells/ $\mu$ l to 225 to 245 cells/ $\mu \mathrm{l}$.

\section{Discussion}

The immune system may be divided into populations of cells that are functionally and kinetically distinct: long-lived progenitor cells with the capacity to produce many progeny and end-stage effector cells destined to die quickly. As is the case in epithelial tissues or the remainder of the hematopoietic system, progenitor cells are necessary for the maintenance of tissue mass in the face of continuous loss of differentiated progeny. $T$ cell progenitors are found at varying levels of the differentiation tree and include multilineage hematopoietic stem cells in the bone marrow, $\mathrm{T}$ lineage-restricted progenitors in the thymus, and naive and "true memory" $\mathrm{T}$ cells in peripheral lymphoid organs, such as spleen and lymph nodes. In vivo studies in rodents have documented the presence of kinetically distinct subpopulations of $\mathrm{T}$ cells, including long-lived populations of cells that retain tritiated thymidine $(26,27)$, but analogous $\mathrm{T}$ cell subpopulations had not previously been demonstrated in humans. Because specific markers are not currently available to identify different types of memory cells, we instead used differences in dynamic behavior of cells within the surface phenotype-defined $\mathrm{m} / \mathrm{e}-\mathrm{T}$ cell population to establish the existence and quantify the relative abundances of these postulated $T$ cell subpopulations. Although we could not physically isolate effector- or memory-type $\mathrm{T}$ cells by this approach, our results clearly demonstrate their presence, quantify their relative contributions in healthy people and in advanced HIV-1 infection, and provide a biomarker for future efforts to identify biochemical correlates and physically isolate these subpopulations.

The combined use of two novel, stable isotope-labeling techniques provided clear evidence for $\mathrm{T}$ cell subpopulations with distinctly different life spans and for differential effects of advanced HIV-1 infection on these subpopulations. The two stable isotope-labeling approaches provided complementary and internally consistent results. The long-term ${ }^{2} \mathrm{H}_{2} \mathrm{O}$ incorporation curves demonstrated nonlinear or biphasic accrual of total and $\mathrm{m} / \mathrm{e}$-phenotype but not naive-phenotype $\mathrm{T}$ cells, consistent with the presence of short-lived and longer-lived subpopulations within the $\mathrm{m} / \mathrm{e}$-phenotype $\mathrm{T}$ cell pool. These results from ${ }^{2} \mathrm{H}_{2} \mathrm{O}$ labeling also excluded alternative explanations, such as a late-input source (15), for biphasic die-away curves (see below). The biphasic die-away kinetics of total and $\mathrm{m} / \mathrm{e}$-phenotype $T$ cells complemented the long-term label incorporation data. The persistent label retention in a sub- set of $\mathrm{T}$ cells after a prolonged die-away period (Figure 3) confirmed that short-lived and much longer-lived $T$ cells are present in humans. Long-term labeling also allowed identification of quiescent (nondividing or rarely dividing) $\mathrm{T}$ cells, functionally distinguished by their failure to divide over 9 weeks of label administration (Figure 2d). Because these cells do not contribute to either immune restoration or immune depletion, the ability to account for their presence is important and is not possible by use of brief labeling protocols. These results provide the first quantitative evidence that longlived and quiescent $T$ cells do indeed predominate in the $\mathrm{T}$ cell pool in humans and determine $\mathrm{T}$ cell pool size, as in rodents $(1,2,8)$, unlike in other tissues in which short-lived cells predominate and determine pool size. Finally, both labeling approaches indicated that the greatest impact of advanced HIV-1 infection is to reduce the generation of long-lived, potential progenitor T cells, whereas effective LT ARV therapy restores the capacity to generate these cells.

The studies described here are methodologically novel in two ways. Most importantly, these are the first long-term labeling studies (i.e., more than a few days or a week of label administration) of T cells in humans. To observe multiphasic kinetics and thereby tease out cells with different turnover rates in any system by use of a continuous labeling strategy, it is necessary to administer label for a considerably longer period than the turnover time of the short-lived pool (i.e., 2-3 weeks for $\mathrm{T}$ cells) $(23,24)$. This had not been possible before the development of the ${ }^{2} \mathrm{H}_{2} \mathrm{O}$-labeling technique (10, 21-23). Second, these are the first studies of long-term label retention in the m/e-surface phenotype compartment of human T cells. Previous studies of T cell delabeling in humans $(15,16)$ had only analyzed total $\mathrm{CD}^{+}$ or CD8 ${ }^{+} \mathrm{T}$ cells. By combining the ${ }^{2} \mathrm{H}_{2} \mathrm{O}$ technique (10) with ${ }^{2} \mathrm{H}$-glucose incorporation/die-away measurements and by using flow cytometry to isolate $T$ cells of defined surface phenotype $(9,14)$, the existence and dynamics of cells with short life span and long life span in the $\mathrm{m} / \mathrm{e}$-phenotype compartment of the human $\mathrm{T}$ cell system could be characterized for the first time.

An important point to emphasize about the techniques used here is that they reveal heterogeneity only in cell death rates, not in proliferation rates. If proliferation rates varied but death rates were constant in $T$ cell subpopulations, the consequence at steady state would be a difference in pool size but no differences in either fractional replacement or die-away rates $(13,24$, 28). Stated differently, the fraction of each subpopulation replaced per day and their subsequent life span would be the same for rapidly proliferating and slowly proliferating subpopulations, and both label incorporation and decay curves would be monoexponential $(13,24)$. Heterogeneity in $\mathrm{T}$ cell proliferation rates would hardly be a novel finding (e.g., related to differences in antigenic stimulation). In contrast, the clear finding of heterogeneity in the fate of $\mathrm{T}$ cells (their survival or death) within the phenotypically defined $\mathrm{m} / \mathrm{e}$ 
$\mathrm{T}$ cell populations is novel in humans and has potential functional importance.

Using BrdU labeling and decay curves, Kovacs et al. (16) also recently concluded that rapidly dividing and slowly dividing subpopulations are present in the total $\mathrm{T}$ cell pool in humans. Although this was a welldesigned study, interpretation of BrdU die-away curves has long been recognized to be highly confounded (reviewed in ref. 13). In particular, retention of BrdU positivity of cells can persist during several generations of cell division. BrdU-label retention cannot therefore be taken to represent a long life span or absence of division in a population of cells (13). Moreover, BrdU dieaway curves do not exhibit monoexponential decay kinetics because persistent BrdU positivity is followed by reduction below a threshold detection level. Biphasic or multiphasic BrdU die-away curves therefore cannot be interpreted in a simple manner $(13,25)$. These problems do not apply to die-away after deuterium labeling of DNA, which accurately quantifies dilution by unlabeled DNA during semiconservative replication (13) and which exhibits monoexponential die-away curves in single pool systems $(13,15)$. Also, Kovacs et al. (16) did not analyze $\mathrm{m} / \mathrm{e}$ - and naive-phenotype $\mathrm{T}$ cells separately, and our results demonstrate that kinetically distinct subpopulations are apparent within the $\mathrm{m} / \mathrm{e}$-phenotype population.

Mohri et al. (15) recently reported that the fractional death rate was 3 to 10 -fold greater than the fractional proliferation rate of T cells in both HIV-1uninfected and -infected humans. When label in a metabolic pool is lost at a higher fractional rate than label is incorporated into the total pool, the traditional kinetic interpretation is that the labeled molecules or cells do not have an identical fate as the total pool $(24,25,28)$, i.e., that kinetically distinct subpopulations are present. Mohri et al. (15) instead proposed a model wherein a "source" contributes cells that are initially unlabeled. Over longer-term labeling, these "source" cells would, of course, have to divide and would therefore slowly contribute labeled cells to the peripheral pool in a manner that should increase over time. The long-term ${ }^{2} \mathrm{H}_{2} \mathrm{O}$-labeling results shown here (Figure 2 ) provide direct evidence against the existence of this postulated "source," i.e., we did not observe accelerated late incorporation of label, as would be predicted if there were delayed input of labeled cells from a large tissue source. Rather, we observed the opposite (reduced late incorporation). More recently, the data of Mohri et al. (15) have been reanalyzed by Ribeiro et al. (29) using a revised model that includes populations of activated (dividing and dying) and resting cells, in place of a "source." This revised model (29) is more consistent with our analysis and results. Three weeks after discontinuing ${ }^{2} \mathrm{H}$-glucose infusions, the fractions of $\mathrm{CD}^{+}$and $\mathrm{CD}^{+} \mathrm{T}$ cells remaining were $57 \% \pm 16 \%$ and $78 \% \pm 28 \%$, respectively, in healthy controls compared with $30 \% \pm 12 \%$ and $40 \% \pm 15 \%$ in untreated
HIV-1/AIDS patients; 5 to 7 weeks after discontinuing ${ }^{2} \mathrm{H}$-glucose, the values for $\mathrm{CD}^{+}$and $\mathrm{CD}^{+} \mathrm{T}$ cells were $46 \% \pm 6 \%$ and $56 \% \pm 21 \%$ in controls and $20 \% \pm 8 \%$ and $28 \% \pm 15 \%$ in HIV-1/AIDS (15). Moreover, the die-away curves generally reached a stable, non-zero value (15). Comparison of proliferation with death rate constants of Mohri et al. (15) suggests that $6 \%$ to $8 \%$ of the $\mathrm{T}$ cell pool is actively dividing in healthy controls and $16 \%$ to $33 \%$ in untreated HIV-1/AIDS patients. All of these values are similar to the results reported here (compare with Figure $2 \mathrm{~d}$ ).

Recognizing the distinction between long-lived (producing) cells and short-lived (presumably effector) cells is essential for understanding $\mathrm{CD} 4^{+} \mathrm{T}$ lymphopenia, the defining feature of HIV-1/AIDS. Our results show that the generation of short-lived subpopulations of $\mathrm{T}$ cells was not impaired in advanced HIV-1/AIDS. Indeed, the absolute rate of proliferation for short-lived cells is somewhat elevated in advanced HIV-1/AIDS compared with healthy controls (approximately 6 vs. 3 cells/ $/$ l of blood per day, Figure 4a). The presence of an increased proportion or total number of cycling cells in HIV-1 infection is not a new observation, having been reported using indirect methods such as Ki67 (30) in addition to labeling approaches $(9,14-16)$. Our quantitative results regarding production rates of long-lived cells, however, are novel and of fundamental relevance to HIV-1 immunopathogenesis. Advanced HIV-1 infection greatly reduced the percent and total number of $\mathrm{CD}^{+} \mathrm{T}$ cells that are long-lived (Figure 4). Because these cells represent the regenerative source of newly formed $\mathrm{CD}^{+}$effector $\mathrm{T}$ cells, their loss may underlie the immunodeficiency of HIV-1 disease. It should be emphasized that the HIV-1/AIDS subjects studied here had relatively advanced HIV-1 disease, with $\mathrm{CD} 4^{+} \mathrm{T}$ cell lymphopenia. These kinetic abnormalities may not be present in early HIV-1 infection and may represent a marker of disease stage or activity (ref. 31; M.K. Hellerstein and J.M. McCune, unpublished observations).

Indeed, death of cells that might otherwise have been long-lived is sufficient to account for $\mathrm{CD}^{+} \mathrm{T}$ lymphopenia of HIV-1/AIDS. By reducing 2 cells/ $\mu \mathrm{l} / \mathrm{d}$, the production of long-lived $\mathrm{m} / \mathrm{e}$-phenotype cells that have an average life span of 3 to 6 months would reduce the $T$ cell pool by 200 to 400 cells/ $\mu l$. In contrast, the production of short-lived m/e-phenotype $T$ cells, by 5 cells/ $\mu \mathrm{l} / \mathrm{d}$ (life span 2-3 weeks), can increase the $T$ cell pool by only 70 to 100 cells/ $\mu l$. Thus, not all forms of $T$ cell turnover are equal: some $\mathrm{T}$ cell proliferative pathways can effectively contribute to immune repletion, whereas others cannot $(7,8,17)$. Combadere et al. (30) recently reported that more than $90 \%$ of Ki67-positive T cells in HIV-1infected patients represent cytokine-secreting effectorlike cells that are not progressing through the cell cycle, but are arrested in G1-phase. Cells of this type could not contribute to $\mathrm{CD}^{+} \mathrm{T}$ cell repletion.

The kinetics of naive-phenotype $\mathrm{T}$ cells also deserves comment. In contrast to $\mathrm{m} / \mathrm{e}$-phenotype $\mathrm{T}$ cells, naivephenotype $T$ cells did not show obvious biphasic or 
nonlinear kinetics either during long-term label incorporation or decay (Figures $2 \mathrm{a}$ and $3 \mathrm{a}$ ). Significantly higher replacement rates were observed for naive $T$ cells in untreated HIV-1 infection, compared with healthy controls or LT ARV-treated patients (Figure $2 \mathrm{~d}$ ) and there was considerable interindividual variability for naive $\mathrm{T}$ cell kinetics in the untreated HIV-1-infected group (note SDs in Figure 2a), consistent with our previous observations (9). The interpretation of accelerated naive $\mathrm{T}$ cell turnover in advanced HIV-1 infection is not certain, but is consistent with a higher rate of recruitment of naive $\mathrm{T}$ cells into the $\mathrm{m} / \mathrm{e}$ population (18). In future studies, it will be of interest to monitor the die-away curves of naivephenotype $\mathrm{T}$ cells that are labeled during long-term ${ }^{2} \mathrm{H}_{2} \mathrm{O}$ administration, to establish whether transitional proliferation of naive-phenotype $\mathrm{T}$ cells en route to the $\mathrm{m} / \mathrm{e}$-pool explains higher flow-through rates in the naive T cell pool in HIV-1 infection.

The results described here are potentially relevant to the pathogenic locus of action of HIV-1. Two key findings argue against the simple model that the rapid die-away of a subpopulation of $\mathrm{CD}^{+} \mathrm{T}$ cells is explained by direct HIV-1 killing of dividing $\mathrm{m} / \mathrm{e}$-phenotype $\mathrm{T}$ cells. First, $\mathrm{CD}^{+}$and $\mathrm{CD} 4^{+} \mathrm{m} / \mathrm{e}$-phenotype $\mathrm{T}$ cells exhibited similar biphasic kinetics, with a greater die-away fraction, and a reduced long-lived fraction of new cells produced for both. It is unlikely that HIV-1-induced cytopathicity could account for premature $\mathrm{CD}^{+} \mathrm{T}$ cell death of this magnitude (32-35). Second, healthy HIV-1-seronegative control subjects also exhibited biphasic kinetics and a subset of short-lived cells in their $\mathrm{m} / \mathrm{e}$-phenotype $\mathrm{T}$ cell pool. It is therefore possible to offer an alternative hypothesis to direct HIV-1 cytopathicity; namely, that some feature of HIV-1 infection alters T cell developmental pathways, reducing the fraction of long-lived (progenitor) cells relative to short-lived (presumably effector) cells generated. Whether the causal agent is HIV-1 itself or the effect is secondary to immune activation $(7,17,18,36)$ or other factors cannot be determined from the current data. Experimental testing of these questions is now possible, however, using the kinetic techniques described here.

Alternate explanations of these results deserve consideration. Grossman et al. $(6,17)$ have proposed that whole-body $\mathrm{T}$ cell dynamics are characterized by cumulative, unsynchronized local bursts of $\mathrm{T}$ cell division and death. If this model is correct and the fate of most amplificatory bursts is activation-induced cell death, long-term labeling with ${ }^{2} \mathrm{H}_{2} \mathrm{O}$ might result in a relatively small cumulative fraction of labeled cells remaining in the $T$ cell pool. Our observation that more than $50 \%$ of $\mathrm{m} / \mathrm{e}$-phenotype $\mathrm{T}$ cells are labeled after 9 weeks of ${ }^{2} \mathrm{H}_{2} \mathrm{O}$ administration and more than $40 \%$ are labeled after only 5 weeks (Figure $2 d$ ) in advanced HIV-1 infection signifies that unsynchronized bursts, if they occur, must directly involve a very high fraction of the total $\mathrm{m} / \mathrm{e}$-phenotype $\mathrm{T}$ cell pool in the body. These bursts must also result in substantial replacement of the cells initially present by surviving postburst progeny. Our results therefore demonstrate that the subset of $\mathrm{T}$ cells that is highly activated and rapidly proliferating in patients with advanced HIV-1 infection cannot represent a minority of the total-body $\mathrm{m} / \mathrm{e}$-phenotype $\mathrm{T}$ cell pool, whether the model is of asynchronous bursts or uniform and constant proliferation.

Finally, the techniques described here for identifying $\mathrm{T}$ cell subpopulations with different life spans may have applications for characterizing the normal antigen-driven $T$ cell proliferative response. Testing the kinetic fate of cells carrying certain surface antigens (e.g., CCR-7 or other markers) $(4,37)$ may help to determine whether these phenotypic markers represent true memory versus effector lineages within dividing $T$ cells. Establishing the consequences of various pathologic or therapeutic factors (e.g., cytokines, progenitor cell availability, etc.) on each phase of the proliferative responses of antigen-specific $T$ cells is also of potential interest for vaccine research (1-5).

\section{Acknowledgments}

We gratefully acknowledge the help of the nurses of the San Francisco General Hospital General Clinical Research Center and the volunteers who made this study possible. This work was supported in part by grants from the National Institutes of Health to M.K. Hellerstein (AI41401 and AI44767), to J.M. McCune (AI43864 and AI40312), an Interactive Research Project Grant to J.M. McCune and M.K. Hellerstein (AI43866), and an unrestricted gift from KineMed Inc. (to M.K. Hellerstein). An NIH grant from the Division of Research Resources (MO1-RR00083) supported the General Clinical Research Center. J.M. McCune is a recipient of the Burroughs Wellcome Fund Clinical Scientist Award in Translational Research.

1. Ahmed, R., and Gray, D. 1996. Immunological memory and protective immunity: understanding their relation. Science. 272:54-60.

2. Rocha, B., Freitas, A.A., and Coutinho, A.A. 1983. Population dynamics of T lymphocytes. Renewal rate and expansion in the peripheral lymphoid organs. J. Immunol. 131:2158-2164.

3. Sallusto, F., Lenig, D., Forster, R., Lipp, M., and Lanzavecchia, A. 1999. Two subsets of memory $\mathrm{T}$ lymphocytes with distinct homing potentials and effector functions. Nature. 401:708-712.

4. Mackay, C.R. 1999. Dual personality of memory T-cells. Nature. 401:659-660

5. Jacob, J., and Baltimore, D. 1999. Modeling T-cell memory by genetic marking of memory T-cells in vivo. Nature. 399:593-597.

6. Grossman, Z., Meier-Schellerscheim, M., Sousa, A.E., Victorino, R.M., and Paul, W.E. 2002. CD4 ${ }^{+}$T-cell depletion in HIV-infection: are we closer to understanding the cause? Nat. Med. 8:319-323.

7. McCune, J.M. 2001. The dynamics of $\mathrm{CD}^{+}$T-cell depletion in HIV disease. Nature. 410:974-979.

8. Sprent, J., and Tough, D.F. 2001. T-cell death and memory. Science. 293: $245-248$

9. McCune, J.M., et al. 2000. Factors influencing T-cell turnover in HIV-1seropositive patients. J. Clin. Invest. 105:R1-R8.

10. Neese, R.A., et al. 2002. Measurement in vivo of proliferation rates of slow turnover cells by ${ }^{2} \mathrm{H}_{2} \mathrm{O}$ labeling of the deoxyribose moiety of DNA. Proc. Natl. Acad. Sci. U. S. A. 99:15345-15350.

11. Perelson, A.S., Essunger, P., and Ho, D.D. 1997. Dynamics of HIV-1 and CD4 ${ }^{+}$lymphocytes in vivo. AIDS. 11(Suppl. A):S517-S524.

12. Ferguson, N.M., et al. 1999. Antigen-driven CD4 ${ }^{+}$T-cell and HIV-1 dynamics: residual viral replication under highly active antiretroviral 
therapy. Proc. Natl. Acad. Sci. U. S. A. 96:15167-15172.

13. Hellerstein, M.K. 1999. Measurement of T-cell kinetics: recent methodologic advances. Immunol. Today. 20:438-441.

14. Hellerstein, M., et al. 1999. Directly measured kinetics of circulating $\mathrm{T}$ lymphocytes in normal and HIV-1-infected humans. Nat. Med. 5:83-89.

15. Mohri, H., et al. 2001. Increased turnover of T lymphocytes in HIV-1 infection and its reduction by antiretroviral therapy. J. Exp. Med. 194:1277-1287.

16. Kovacs, J.A., et al. 2001. Identification of dynamically distinct subpopulations of T lymphocytes that are differentially affected by HIV. J. Exp. Med. 194:1731-1741.

17. Grossman, Z., Feinberg, M.B., and Paul, W.E. 1998. Multiple modes of cellular activation and virus transmission in HIV infection: a role for chronically and latently infected cells in sustaining viral replication. Proc. Natl. Acad. Sci. U. S. A. 95:6314-6319.

18. Hazenberg, M.D., Hamann, D., Schuitemaker, H., and Miedema, F. 2000 T cell depletion in HIV infection: how $\mathrm{CD}^{+}{ }^{+} \mathrm{T}$ cells go out of stock. Nat. Immunol. 1:285-289.

19. Macallan, D.C., et al. 1998. Measurement of cell proliferation by labeling of DNA with stable isotope-labeled glucose: studies in vitro, in animals, and in humans. Proc. Natl. Acad. Sci. U. S. A. 95:708-713.

20. Neese, R.A., et al. 2001. Advances in the stable isotope-mass spectrometric measurement of DNA synthesis and cell proliferation. Anal. Biochem. 298:189-195.

21. Antelo, F., Neese, R., and Hellerstein, M. 2000. Measuring adipocyte proliferation in vivo using ${ }^{2} \mathrm{H}_{2} \mathrm{O}$ incorporation into DNA. FASEB J. 24:A214. (Abstr.)

22. Collins, M.L., Eng, S., Rebeccah, H., and Hellerstein, M.K. 2003. Measurement of mitochondrial DNA synthesis in vivo in rodents and humans using a stable isotope-mass spectrometric technique. J. Appl. Physiol. 94:2203-2211.

23. Misell, L., et al. 2000. A new in vivo stable isotope method using ${ }^{2} \mathrm{H}_{2} \mathrm{O}$ for measuring mammary epithelial cell proliferation. FASEB J. 14:A786. (Abstr.)

24. Hellerstein, M.K., and Neese, R.A. 1999. Mass isotopomer distribution analysis at eight years: theoretical, analytic, and experimental considerations. Am. J. Physiol. 276:E1146-E1170.

25. Aarnaes, E., Kirkhus, B., and Clausen, O.P. 1990. Mathematical model analysis of mouse epidermal cell kinetics measured by bivariate DNA/ anti-bromodeoxyuridine flow cytometry and continuous ${ }^{3} \mathrm{H}$-thymidine labeling. Cell Tissue Kinet. 23:409-424.

26. Caffrey, R.W., Rieke, W.O., and Everett, N.B. 1962. Radioautographic studies of small lymphocytes in the thoracic duct of the rat. Acta. Haemat. 28:145-154.

27. Miller, J.J. 1964. An autoradiographic study of plasma cells and lymphocyte survival in the rat popliteal lymph nodes. J. Immunol. 92:673-681.

28. 1978. Protein turnover in mammalian tissues and in the whole body. J.C. Waterlow, P.J. Garlick, and D.J. Millward, editors. North-Holland Publishing Co. Amsterdam, The Netherlands. 804 pp.

29. Ribeiro, R.M., Mohri, H., Ho, D.D., and Perelson, A.S. 2002. In vivo dynamics of $\mathrm{T}$ cell activation, proliferation, and death in HIV-1 infection: why are $\mathrm{CD}^{+}$but not $\mathrm{CD}^{+}$T cells depleted? Proc. Natl. Acad. Sci. U. S. A. 99:15572-15577.

30. Combadere, B., et al. 2000. CD4 ${ }^{+} \mathrm{Ki} 67^{+}$lymphocytes in HIV-infected patients are effector $\mathrm{T}$ cells accumulated in the $\mathrm{G} 1$ phase of the cell cycle. Eur. J. Immunol. 30:3598-3603.

31. Deeks, S.G., et al. 2002. CD4 ${ }^{+} \mathrm{T}$ cell kinetics and activation in human immunodeficiency virus-infected patients who remain viremic despite long-term treatment with protease inhibitor-based therapy. J. Infect. Dis. 185:315-323.

32. Finkel, T.H., et al. 1995. Apoptosis occurs predominantly in bystander cells and not in productively infected cells of HIV- and SIV-infected lymph nodes. Nat. Med. 1:129-134.

33. Clapham, P.R., and McKnight, A. 2001. HIV-1 receptors and cell tropism. Br. Med. Bull. 58:43-59.

34. Rosok, B.I., et al. 1998. Correlates of apoptosis of $\mathrm{CD}^{+}{ }^{+}$and $\mathrm{CD} 8^{+} \mathrm{T}$-cells in tonsillar tissue in HIV type 1 infection. AIDS Res. Hum. Retroviruses. 14:1635-1643.

35. Dyrhol-Riise, A.M., et al. 2001. T cell proliferation and apoptosis in HIV-1infected lymphoid tissue: impact of highly active antiretroviral therapy. Clin. Immunol. 101:180-191.

36. Anderson, R.W., Ascher, M.S., and Sheppard, H.W. 1998. Direct HIV cytopathy cannot account for CD4 decline in AIDS in the presence of homeostasis: a worst-case dynamic analysis. J. AIDS Hum. Retrovir. 17:245-252.

37. Hamann, D., et al. 1997. Phenotypic and functional separation of memory and effector human CD8 ${ }^{+}$T-cells. J. Exp. Med. 186:1407-1418. 